\title{
Performance Evaluation of Regional Rural Banks in India
}

\author{
Dr. M.SYED IBRAHIM \\ Assistant Professor, Sona School of Management \\ (A Unit of Sona College of Technology) \\ T.P.T.Road, Salem, Tamil Nadu, South India-636 005 \\ E-mail: syedibrahim_66@yahoo.co.in
}

\begin{abstract}
Regional Rural Banks are established under the provisions of an ordinance promulgated on the $26^{\text {th }}$ September, 1975 and the RRB Act, 1976 with an objective to ensure sufficient institutional credit for agriculture and other rural sectors. Reforms and mergers introduced by the Government of India in consultation with Reserve Bank of India (RBI) and National Bank for Agriculture and Rural Development (NABARD) in the years 1994-95 to 2005-06 have yielded positive results in respect of key performance indicators such as number of banks and branches, capital composition, deposits, loans, loans and the trend of investments. The objective of this paper is to investigate whether the merger/amalgamation of Regional Rural Banks in India, undertaken in $2005-06$ has helped improve their performance. Several committees have emphasized the need to improve the performance of these banks which play an important role in the rural credit market in India. The study is diagnostic and exploratory in nature and makes use of secondary data. The study finds and concludes that performance of rural banks in India has significantly improved after amalgamation process which has been initiated by the Government of India.
\end{abstract}

Keywords: Rural Credit Market, Performance, State Governments, Sponsor, Reserve Bank of India

\section{Introduction}

Banks play an important role in mobilization and allocation of resources in any country. Rural people in India are facing problems in the inadequate supply of credit. The major source of credit to rural households, particularly-low income working households, has been the informal sector. Informal sector advances loans at very high rates of interest; the terms and conditions attached to such loans have given rise to an elaborate structure of intimidation of both economic and non-economic conditions in rural population in India. RRBs were established in India in 1975 essentially for the purpose of taking banking service to the doorsteps of rural people, particularly in places without banking facilities.

The objectives as given in the preamble of RRBs Act of 1976 were "to develop the rural economy in providing for the purpose of development of agriculture, trade commerce, industry and other productive activities $n$ the rural areas, credit and other facilities particularly to the small and marginal farmers, agricultural labourers, artisans and small entrepreneurs and for matter connected therewith and incidental thereto"

Several changes have taken place in the focus and operation of the Regional Rural Banks in the wake of financial sector reforms in India and various measures have been taken by the Government to improve the commercial viability of RRBs since 1994-95. So it has been considered appropriate to study the performance after amalgamation which took place in the year 2006.A study of the efficiency and its performance of the RRB are particularly important in the Indian context. The objective of this study is to analyze the performance of RRBs during pre and post-merger periods. The indicators selected to study the performance of the RRBs are number of RRBs and branches, geographical coverage, manpower deployment, capital funds, deposits mobilization, loans outstanding and investment made by the RRBs. The paper is organized as follows:

A brief review of the RRBs in India is provided in section-2. In section-3, review of literature is presented. Methodology is discussed in section-4. Section-5 presents the results and analysis and conclusion of this paper is presented in section-6.

\section{An Overview of Indian Regional Rural Banks (RRBs)}

In India rural people such as small and marginal farmers, landless agricultural laborers, artisans and socially and economically backward castes and classes they have been exploited in the name of credit facility by informal sector. The rural credit market consists of both formal and informal financial institutions and agencies that meet the credit needs of the rural masses in India. The supply of total formal credit is inadequate and rural credit markets are imperfect and fragmented. Moreover, the distribution of formal sector credit has been unequal, particularly with respect to region and class, cast and gender in the country side. 
Regional Rural Banks were established under the provisions of an Ordinance promulgated on the $26^{\text {th }}$ September 1975 and the RRB Act, 1975 with an objective to ensure sufficient institutional credit for agriculture and other rural sectors. The RRBs mobilize financial resources from rural/semi-urban areas and grant loans and advances mostly to small and marginal farmers, agricultural laborers and rural artisans. For the purpose of classification of bank branches, the Reserve bank of India defines rural area as a place with a population of less than 10,000.RRBs are jointly owned by Government of India, the concerned State Government and Sponsor Banks; the issued capital of a RRB is shared by the owners in the proportion of $50 \%, 15 \%$ and $35 \%$ respectively. The first five RRBs were set up in five States in Haryana, West Bengal, Rajasthan, with one each two in Uttar Pradesh, which were sponsored by different commercial banks. These banks covered 11 districts of these five states. The first five Regional Rural Banks are as follows;

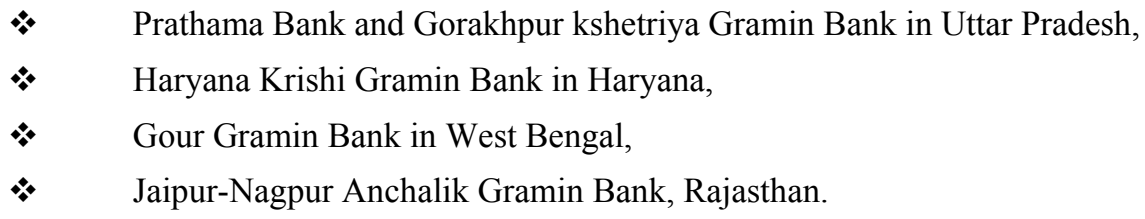

\section{Reform \& Merger Process}

In the wake of introduction of financial sector reforms in 1991-92, the commercial viability of RRBs emerged as the most crucial factor in deciding about their desired role due to their limited business flexibility with hardly any scope of expansion/diversification, smaller size of loans with higher exposure to risk-prone advances and professional efficiency in financial deployment. To strengthen RRBs and improve their performance many initiatives have been taken by the Government of India and the Reserve Bank of India (RBI). As part of the comprehensive restructuring programme, recapitalization of RRBs was initiated in the year 1994-95. The process continued till 1990-00 and covered 187 RRBs with aggregate financial support of Rs.2188.44 crore from the shareholders, viz., Government of India, State Governments and sponsor Banks in the ratio of 50:15:35. Further, the branch licensing policy for RRBs has been liberalized. Under the new norms, empowered committees at the regional offices of RBI clear RRB application to open new branches. The branches of RRBs may undertake government business including conducting foreign exchange business with the prior approval of the concerned Government authority and RBI. These banks have also been allowed to open extension counters at the premises of the institutions of which they are principal bankers after obtaining license from the concerned regional office of the RBI. The RRBs need not obtain permission of RBI for the installation of ATMs at the branches and extension counters for which they hold licenses issued by RBI. They are also permitted to open off-site ATMs after assessing the cost and benefit. As against the earlier policy of opening a large number of branches in far flung rural areas, RRBs have been permitted to merge/close down their unviable branches and the branch licensing policy for RRBs is almost at par with that for commercial banks. Now RRBs compete with the commercial banks in rural credit market of India. RRBs give loans for agriculture and rural development while commercial banks also serve needs of commerce and industry in rural areas.

In 2005-06, the Government of India initiated the process of structural consolidation of RRBs by amalgamating RRBs sponsored by the same bank within a State as per the recommendations of the Vyas Committee (2004). The amalgamated RRBs were expected to provide better customer service due to better infrastructure, computerization of branches, pooling of experienced work force, common publicity, marketing efforts etc., and also derive the benefits of a large area of operation, enhanced credit exposure limits and more diverse banking activities. As a result of the amalgamation, the number of RRBs was reduced from 196 to 86 as on $31^{\text {st }}$ March, 2009. Thus, under the amalgamation process, $145 \mathrm{RRBs}$ have been amalgamated to form 45 new RRBs.

\section{Review of Literature}

The literature available in the working and performance of RRBs in India is a little limited. The literature obtained by investigators in the form of reports of various committees, commissions and working groups established by the Union Government, NABARD and Reserve Bank of India, the research studies, articles of researchers, bank officials, economists and the comments of economic analysts and news is briefly reviewed in this part.

Patel and Shete (1980) of the National Institute of Banking Management made a valuable analysis of performance and prospects of RRBs. They also gave a comparative picture of performance in deposits, branch expansion and credit deployment of the co-operative banks, commercial banks and RRBs in a specified area. This was an eye opener for many researchers engaged in this field of rural credit. 
NABARD (1986) published "A study on RRBs viability", which was conducted by Agriculture Finance Corporation in 1986 on behalf of NABARD. The study revealed that viability of RRBs was essentially dependent upon the fund management strategy, margin between resources mobility and their deployment and on the control exercised on current and future costs with advances. The proportion of the establishment costs to total cost and expansion of branches were the critical factors, which affected their viability. The study further concluded that RRBs incurred losses due to defects in their systems as such, there was need to rectify these and make them viable. The main suggestions of the study included improvement in the infrastructure facilities and opening of branches by commercial banks in such areas where RRBs were already in function.

Kalkundrickars (1990) in his study on "Performance and Growth of regional Rural Banks in Karnataka" found that these banks had benefited the beneficiaries in raising their income, productivity, employment and use of modern practices and rehabilitate rural artisans.

Kumar Raj (1993) carried out a study on the topic "Growth and Performance of RRBs in Haryana". On the basis of the study of RRBs of Haryana, it is found that there was an enormous increase in deposits and outstanding advances. The researcher felt the need to increase the share capital and to ensure efficient us of distribution channels of finance to beneficiaries.

A. K. Jai Prakash (1996) conducted a study with the objective of analyzing the role of RRBs in Economic Development and revealed that RRBs have been playing a vital role in the field of rural development. Moreover, RRBs were more efficient in disbursal of loans to the rural borrowers as compared to the commercial banks. Support from the state Governments, local participation, and proper supervision of loans and opening urban branches were some steps recommended to make RRBs further efficient.

L.K Naidu (1998) conducted a study on RRBs taking a sample of 48 beneficiaries of rural artisans in Cuddapah district of Andhra Pradesh state under Rayale Seen Gramin Bank. In this study, it was concluded that the beneficiaries were able to find an increase in their income because of the finance provided by the bank.

According to Nathan, Swami (2002), policies of current phase of financial liberalization have had an immediate, direct and dramatic effect on rural credit. There has been a contraction in rural banking in general and in priority sector ending and preferential lending to the poor in particular.

Chavan and Pallavi (2004) have examined the growth and regional distribution of rural banking over the period 1975-2002. Chavan's paper documents the gains made by historical underprivileged region of east, northeast and central part of India during the period of social and development banking. These gains were reversed in the 1990s: cutbacks in rural branches in rural credit deposits ratios were the steepest in the eastern and northeastern states of India. Policies of financial liberalization have unmistakably worsened regional inequalities in rural banking in India.

Professor Dilip Khankhoje and Dr. Milind Sathye (2008) have analysed to measure the variation in the performance in terms of productive efficiency of RRBs in India and to assess if the efficiency of these institutions has increased post-restructuring in 1993-94.

As none of these studies analyze the performance after amalgamation took place in the year 2006, there is a need for carrying out the present study.

\section{Methodology/Research Design}

The present study is diagnostic and exploratory in nature and makes use of secondary data. The relevant secondary data have been collected mainly through the data bases of Reserve Bank of India (RBI), National Bank for Agricultural and Rural Development (NABARD). The journals like the Banker and the Journal of Indian Institute of Bankers have also been referred. The study is confined only to the specific areas like number of branches, district coverage, deposits mobilized, credits and investments made by the Indian Regional Rural Banks (RRBs) for the eight years period starting from 2001-02 to the year 2008-09. In order to analyze the data and draw conclusions in this study, various statistical tools like ' $t$ ' test and ANOVA have been accomplished through EXCEL and SPSS Software.

\section{Results and Discussion}

\section{Growth of Regional Rural Banks in India}

Till the birth of RRBs in India, Commercial Banks and Co-operative Banks were rendered services to the rural public. But despite such large net work of bank branches, the credit needs of the rural population in India were quite inadequate. Regional Rural Banks in India have achieved tremendous growth in terms of number of banks and its wide braches which is shown in the Table-1 
It is very clear from the table 1 that the number of RRBs decreased from 196 in the year 2001-02 to 86 in 2008-09. This was due to the amalgamation that took place in the year 2005-2006, covering 525 districts with a net work of 14,494 branches. However, the number of branches has been significantly increased from 14,390 in 2001-02 to 15,181 in 2008-09. The increase over the period was 1.05 times.

A paired t-test was performed to determine whether the pre-merger period performance significantly differs from the post-merger period performance of the Regional Rural Banks in India. The Hypotheses framed are as follows:

HO: There is no difference in performance between the pre-merger period and post- merger period.

H1: There is difference in performance between the pre-merger period and post- merger period. The test results are furnished in Table-2

Tables 2 provides the result that there is strong evidence that $(\mathrm{t}$ is $<3.182446)$, there is difference in the pre-merger and post-merger performance of the RRBs. (i.e., HO is accepted)

\section{Geographical Coverage and Man Power Deployment}

Regional Rural Banks (RRBs) were established in India essentially for taking banking to the doorsteps of rural masses, particularly in areas without banking facilities. RRB is a bank for rural poor people; its presence in all the states of country especially in underdeveloped states and union territories is strongly realized. RRBs covered 525 out of 605 districts as on $31^{\text {st }}$ March, 2006. After amalgamation, RRBs have become quite large covering most parts of the states in India. Year-wise coverage of districts and number of branches are given in Table-3

Significant improvement in the performance of RRBs was witnessed over the period of study in terms of number of districts covered. RRBs covered 511 districts as on $31^{\text {st }}$ March, 2002 increased to 616 as on $31^{\text {st }}$ March, 2009. The increase over the period was 1.20 times. However, the human resources employed by RRBs have been considerably decreased year by year owing to the efficiency of the bank.

A paired t-test was performed to determine whether the pre-merger period performance is significantly differs from the post-merger period performance of the Regional Rural Banks in India. The Hypotheses framed are as follows:

HO: There is no difference in performance between the pre-merger period and post- merger period.

H1: There is difference in performance between the pre-merger period and post- merger period. The test results are furnished in Table-4

The result from the table 4 shows that there is strong evidence that ( $\mathrm{t}$ is $<4.302653)$, there is difference in the pre-merger and post-merger performance of the RRBs. (i.e., HO is accepted)

\section{Capital Composition}

RRBs occupy an important position in the rural credit market of India. The rationale for establishment of the RRB was to mobilize deposits, access to central money market and modernized outlook, which the commercial banks have. Sound financial position is essential for any organization to survive to render the services to the society. RRBs have both types of capital i.e., owned and borrowed. The detailed components of capital funds are furnished in Table-5

Table-5 reveals that the year-wise components of total capital comprises of owned funds and borrowed funds of RRBs in India. Both the owned funds and borrowed funds have constantly been increased over the period of study. It is important to observe from the above table that the borrowed funds constitute more percentage than the owned funds during the post-merger period especially the year 2005-2006 onwards.

A paired t-test was performed to determine whether the pre-merger period performance significantly differs from the post-merger period performance of the total funds of the Regional Rural Banks in India. The Hypotheses framed are as follows:

HO: There is no difference in performance between the pre-merger period and post- merger period.

H1: There is difference in performance between the pre-merger period and post- merger period. The test results are given in Table- 6

The result from the table 6 indicates that there is strong evidence that $(\mathrm{t}$ is $<4.302653)$, there is difference in the pre-merger and post-merger performance of the RRBs. (i.e., HO is accepted)

The merger process took place in the year 2005-06. The performance of the owned funds and borrowed funds of the RRBs were compared using ANOVA to test whether the merger process has resulted in improving the 
performance in terms of the owned funds and borrowed funds of these banks in India during the study period. The Hypotheses framed are as follows:

HO: There is no difference in performance between these two funds.

H1: There is difference in performance between these two funds.

The test results are given in Table- 7 .

The mean level of owned funds (6740) is less than that of borrowed funds (7593.875). According to the test result, $\mathrm{F}=0.363978$. With a critical value of. .05 , the critical $\mathrm{F}=4.60011$. Therefore, since the $\mathrm{F}$ statistic is smaller than the critical value, we fail to reject the null hypothesis that there is no difference in the owned funds and borrowed funds of the RRBs.

\section{Deposits and Loans Outstanding Of RRBs}

RRBs are expected to mobilize resources from rural areas and play a significant role in developing agriculture and rural economy by deploying mobilized resources in rural sectors for the needy not conversed by other formal credit institutions. The businesses performance of RRBs in terms of deposit mobilization and credit extension is presented in Table- 8 .

RRB' is showing considerable improvement in their credit and deposits performance. The deposits mobilized by the bank has been increased from Rs.44, 539 crore in the year 2001-02 to Rs.1, 20,189 crore in 2008-09. The increase over the period was 2.7 times. Loans outstanding of the RRBs also highlighted the significant improvement as it has been increased from Rs.18,629 crore in the year 2001-02 to Rs.67,802 crore is 2008-09. The increase over the period of the study was 3.6 times.

The performance of the pre-merger period and post-merger period of the RRBs were compared using ANOVA to test whether the merger process has resulted in improving the performance of these banks in India during the study period.

The Hypotheses framed are as follows:

HO: There is no difference in performance between loans and investments of the RRBs

H1: There is difference in performance between loans and investments of the RRBs.

The test results are given in Table-9. The mean level of loans (39345.38) is less than that of investments (42226.25). According to the test result, $\mathrm{F}=0.148846$. With a critical value of. .05 , the critical $\mathrm{F}=4.60011$. Therefore, since the F statistic is smaller than the critical value, we, fail to reject the null hypothesis that there is no difference in the loans and investments of the RRBs.

\section{Credit Deposit Ratio}

The RRBs were conceived to develop rural economy by providing credit and other facilities for the purpose of development of agriculture, trade and other productive activities to the targeted poor people. The credit deposit ratio of the bank indicates the creation of credit out of the deposits mobilized by the banks which has been furnished in Table-10. The table exhibits that CD ratio increased from 41.8 in the year 2001-02 to 56.4 in 2008-09.There has been consistent growth in the sphere of credit deposit ratio. The year 2007-08 registered a higher rate i.e., $59.5 \%$.

\section{Growth of Investments}

Investment as a window of deployment of funds was given more emphasis than lending. The year-wise investment made by the banks is presented in Table-11.

There has been consistent growth in the sphere of investment activity. It has been observed from the above table that the amount of investment of the bank has been increased from Rs 30,532 crore in the year 2001-02 to Rs 65,910 crore in 2008-09. The year 2008-09 registered at a highest percentage.

\section{Conclusion}

Depending on the context and applications, the term 'performance' may have different connotations. In the present study, the performance of Regional Rural Banks, an attempt has been made to analyze the performance in terms of certain defined parameters like number of branches, district covered, capital funds, and mobilization of deposits, loans and investments made by these banks. The performance of RRBs in India improved in the post-merger period. Even though number of RRBs decreased, the branch net work has been increased. During post-merger period, there has been increased number of districts covered by the RRBs. Total capital funds have been increased tremendously after amalgamation took place in the year 2005-06.Credit-deposit ratio has been 
increased over the years showing that a remarkable deployment of credit by these banks in rural areas. However, it is the responsibility of the bank management and the sponsored banks to take the change for corrective steps to raise the credit-deposit ratio of the bank. The gap between $\mathrm{CD}$ ratio of commercial banks and the RRBs need to be minimized. With a view to facilitate the seamless integration of RRBs with the main payment system, there is a need to provide computerization support to them. RRBs should extend their services in to un-banked areas and increase their credit-deposit ratio. The process of merger should not proceed beyond the level of sponsor bank in each state. The findings may be of considerable use to rural banking institutions and policy makers in developing countries and to academic researchers in the area of banking performance evaluation.

\section{References}

Avkiran, N.K. (1999). The Evidence of Efficiency Gains: The role of mergers and the benefits to the public. Journal of Banking and Finance 23, 991-1013.

Ellinger, P. (1994). Potential Gains from Efficiency Analysis of Agricultural Banks. American Journal of Agricultural Economics, 76 (3) pp.652-654.

Government of India Report of the Committee on Rural Banks, (Chairman-M, Narasimhan), New Delhi, 1975.

Gupta, R.V. (1998). Report of the High-Level Committee on Agricultural Credit through Commercial Banks. Reserve Bank of India, Mumbai.

IBA (Indian Banks' Association), (1999). Performance Highlights of Banks, 1997-98, Indian Banks Association, Mumbai.

Karam Pal and Jasvir Singh. (2006). "Efficacy of Regional Rural Banks (RRBs) In India: A Conventional Analysis", JIMS-8M, Indian Journals.com.

Mester, L.J. (1996). "A Study of Bank Efficiency taking into account Risk Preferences”, Journal of Banking and Finance, Vol.20, No.6, 1025-45.

Misra, B. (2006). The Performance of Regional rural banks (RRBs) in India: Has past Anything to Suggest for future? Reserve Bank of India Occasional Papers, 27 (1), Reserve Bank of India, Mumbai.

Narasimhan Committee. (1991). Report of the Committee on the Financial System, Government of India.

Parliament of India (Loksabha), (2004). Motion for consideration of 'The Regional Rural Banks (Amendment) Bill, 2004.

Professor Dilip Khankhoje and Dr. Milind Sathye, 2008. "Efficiency of Rural Banks: The Case of India", International Business Research-CCSE, Vol-1, No.2.

Rangarajan, C. 1995. 'Inaugural address at the $18^{\text {th }}$ Bank Economists' Conference', Reserve Bank of India Bulletin, December, XLIX (12), Reserve bank of India, Mumbai.

Report on the Trend and Progress of Banking in India 1995-96, Reserve Bank of India Bulletin, March 1007, 34-35.

Sathye, M. (1997). 'Lending Costs, Margins and Financial Viability of Rural Lending Institutions in South Korea', Spellbound Publications, Rohtak, India.

Sathye, M. (2001). "X-efficiency in Australian Banking: An Empirical Investigation", Journal of Banking and Finance, 25,613-630.

Second Narasimhan Committee. (1997). Committee on Banking Sector Reform, Gazette of India-Extraordinary

Notification, Part II, Sec 3 (ii), Ministry of Finance, Government of India.

Subramanyam G. (1993). "Productivity Growth in India's Public Sector Banks: 1979-89", Journal of Quantitative Economics, 9, 209-223.

Thakur, S. (1990). Two Decades of Indian Banking: The Service Sector Scenario, Chanakya Publications New Delhi, India.

Tyagarajan, M. (1975). "Expansion of Commercial Banking- An Assessment”, Economic and Political Weekly, $10,1819-1824$. 
Table-1. Growth of Regional Rural Banks in India

\begin{tabular}{|l|l|l|}
\hline Years & Number of RRBs & Number of Branches \\
\hline $2001-02$ & 196 & 14,390 \\
\hline $2002-03$ & 196 & 14,433 \\
\hline $2003-04$ & 196 & 14,446 \\
\hline $2004-05$ & 133 & 14,484 \\
\hline $2005-06$ & 94 & 14,494 \\
\hline $2006-07$ & 90 & 14,520 \\
\hline $2007-08$ & 90 & 14,761 \\
\hline $2008-09$ & 86 & 15,181 \\
\hline
\end{tabular}

Source: Central Statistical Information Department, NABARD, June-2009.

Table-2. t-Test results-Number of Branches of RRBs

\begin{tabular}{|l|l|l|}
\hline & Post-Merger & Pre-Merger \\
\hline Mean & 14739 & 14438.25 \\
\hline Variance & 101278 & 1502.917 \\
\hline Observations & 4 & 4 \\
\hline Pearson Correlation & 0.901403 & \\
\hline Hypothesized Mean Difference & 0 & \\
\hline$d f$ & 3 & \\
\hline$t$ Stat & 2.119497 & \\
\hline $\mathrm{P}(\mathrm{T}<=\mathrm{t})$ one-tail & 0.062121 & \\
\hline $\mathrm{t}$ Critical one-tail & 2.353363 & \\
\hline $\mathrm{P}(\mathrm{T}<=\mathrm{t})$ two-tail & 0.124242 & \\
\hline $\mathrm{t}$ Critical two-tail & 3.182446 & \\
\hline
\end{tabular}

Table-3. Coverage of Districts and Manpower Deployment

\begin{tabular}{|l|l|l|}
\hline Years & Number of Districts Covered & Number of Staff Employed \\
\hline $2001-02$ & 511 & 69,876 \\
\hline $2002-03$ & 516 & 69,547 \\
\hline $2003-04$ & 518 & 69,249 \\
\hline $2004-05$ & 523 & 68,912 \\
\hline $2005-06$ & 525 & 68,629 \\
\hline $2006-07$ & 534 & 68,289 \\
\hline $2007-08$ & 594 & 68,005 \\
\hline $2008-09$ & 616 & 68,526 \\
\hline
\end{tabular}

Source: Central Statistical Information Department, NABARD, June-2009.

Table-4. t-Test results- Number of Districts Covered by RRBs

\begin{tabular}{|l|l|l|}
\hline & Post-Merger & Pre-Merger \\
\hline Mean & 519 & 581.3333 \\
\hline Variance & 13 & 1801.333 \\
\hline Observations & 3 & 3 \\
\hline Pearson Correlation Mean & 0.875661 & \\
\hline $\begin{array}{l}\text { Hypothesized } \\
\text { Difference }\end{array}$ & 0 & \\
\hline $\mathrm{df}$ & 2 & \\
\hline $\mathrm{t}$ Stat & -2.74555 & \\
\hline $\mathrm{P}(\mathrm{T}<=\mathrm{t})$ one-tail & 0.055502 & \\
\hline $\mathrm{t}$ Critical one-tail & 2.919986 & \\
\hline $\mathrm{P}(\mathrm{T}<=\mathrm{t})$ two-tail & 0.111004 & \\
\hline $\mathrm{t}$ Critical two-tail & 4.302653 & \\
\hline
\end{tabular}


Table-5. Components of Total Capital /Funds (Rs Crore)

\begin{tabular}{|l|l|l|l|l|l|}
\hline Years & $\begin{array}{l}\text { Owned } \\
\text { Funds }\end{array}$ & $\%$ to Total Funds & $\begin{array}{l}\text { Borrowed } \\
\text { Funds }\end{array}$ & \% to Total Funds & Total Funds \\
\hline $2001-02$ & 4,059 & 47.30 & 4,524 & 52.70 & $8,583(100 \%)$ \\
\hline $2002-03$ & 4,666 & 49.30 & 4,799 & 50.70 & $9,465(100 \%)$ \\
\hline $2003-04$ & 5,438 & 54.20 & 4,595 & 45.80 & $10,033(100 \%)$ \\
\hline $2004-05$ & 6,181 & 52.80 & 5,524 & 47.20 & $11,705(100 \%)$ \\
\hline $2005-06$ & 6,647 & 47.65 & 7,303 & 52.35 & $13,950(100 \%)$ \\
\hline $2006-07$ & 7,286 & 42.70 & 9,776 & 57.30 & $17,062(100 \%)$ \\
\hline $2007-08$ & 8,733 & 43.17 & 11,494 & 56.83 & $20,227(100 \%)$ \\
\hline $2008-09$ & 10,910 & 46.14 & 12,736 & 53.86 & $23,646(100 \%)$ \\
\hline
\end{tabular}

Source: Central Statistical Information Department, NABARD, June-2009.

Table-6. t-Test results - Total Funds of the RRBs

\begin{tabular}{|l|l|l|}
\hline & Post-Merger & Pre-Merger \\
\hline Mean & 10401 & 20311.67 \\
\hline Variance & 1355968 & 10842640 \\
\hline Observations & 3 & 3 \\
\hline Pearson Correlation Mean & 0.967675 & \\
\hline $\begin{array}{l}\text { Hypothesized } \\
\text { Difference }\end{array}$ & 0 & \\
\hline$d f$ & 2 & \\
\hline$t$ Stat & -7.85326 & \\
\hline $\mathrm{P}(\mathrm{T}<=\mathrm{t})$ one-tail & 0.007915 & \\
\hline $\mathrm{t}$ Critical one-tail & 2.919986 & \\
\hline $\mathrm{P}(\mathrm{T}<=\mathrm{t})$ two-tail & 0.01583 & \\
\hline $\mathrm{t}$ Critical two-tail & 4.302653 & \\
\hline
\end{tabular}

Table-7. ANOVA (Single Factor) (Owned Funds and Borrowed Funds)

Summary

\begin{tabular}{|l|l|l|l|l|}
\hline Groups & Count & Sum & Average & Variance \\
\hline Owned Funds & 8 & 53920 & 6740 & 5023519 \\
\hline Borrowed Funds & 8 & 60751 & 7593.875 & 11001685 \\
\hline
\end{tabular}

ANOVA

\begin{tabular}{|l|l|l|l|l|l|l|}
\hline Source of Variation & SS & df & MS & F & P-Value & F-Crit \\
\hline Between Groups & 2916410 & 1 & 2916410 & 0.363978 & 0.555954 & 4.60011 \\
\hline Within Groups & $1.12 \mathrm{E}+08$ & 14 & 8012602 & & & \\
\hline & & & & & & \\
\hline Total & $1.15 \mathrm{E}+08$ & 15 & & & & \\
\hline
\end{tabular}

Table-8. Deposits and Loans Outstanding of RRBs in India (Rs.Crore)

\begin{tabular}{|l|l|l|}
\hline Years & Deposits & Loans \\
\hline $2001-02$ & 44,539 & 18,629 \\
\hline $2002-03$ & 50,098 & 22,158 \\
\hline $2003-04$ & 56,350 & 26,114 \\
\hline $2004-05$ & 62,143 & 32,870 \\
\hline $2005-06$ & 71,329 & 39,713 \\
\hline $2006-07$ & 83,144 & 48,493 \\
\hline $2007-08$ & 99,093 & 58,984 \\
\hline $2008-09$ & $1,20,189$ & 67,802 \\
\hline
\end{tabular}

Source: Central Statistical Information Department, NABARD, June-2009. 
Table-9. ANOVA (Single Factor)-Loans and Investments of RRBs

Summary

\begin{tabular}{|l|l|l|l|l|}
\hline Groups & Count & Sum & Average & Variance \\
\hline Loans & 8 & 314763 & 39345.38 & $3.17 \mathrm{E}+08$ \\
\hline Investments & 8 & 337810 & 42226.25 & $1.29 \mathrm{E}+08$ \\
\hline
\end{tabular}

ANOVA

\begin{tabular}{|l|l|l|l|l|l|l|}
\hline $\begin{array}{l}\text { Source of } \\
\text { Variation }\end{array}$ & SS & df & MS & F & P-Value & F-Crit \\
\hline Between Groups & 33197763 & 1 & 33197763 & 0.148846 & 0.70544 & 4.60011 \\
\hline Within Groups & $3.12 \mathrm{E}+09$ & 14 & $2.23 \mathrm{E}+08$ & & & \\
\hline & & & & & & \\
\hline Total & $3.16 \mathrm{E}+09$ & 15 & & & & \\
\hline
\end{tabular}

Table-10. Credit Deposits Ratio of RRBs in India (\%)

\begin{tabular}{|l|l|}
\hline Years & CD Ratio \\
\hline $2001-02$ & 41.8 \\
\hline $2002-03$ & 44.2 \\
\hline $2003-04$ & 46.3 \\
\hline $2004-05$ & 52.8 \\
\hline $2005-06$ & 55.6 \\
\hline $2006-07$ & 58.3 \\
\hline $2007-08$ & 59.5 \\
\hline $2008-09$ & 56.4 \\
\hline
\end{tabular}

Source: Central Statistical Information Department, NABARD, June-2009.

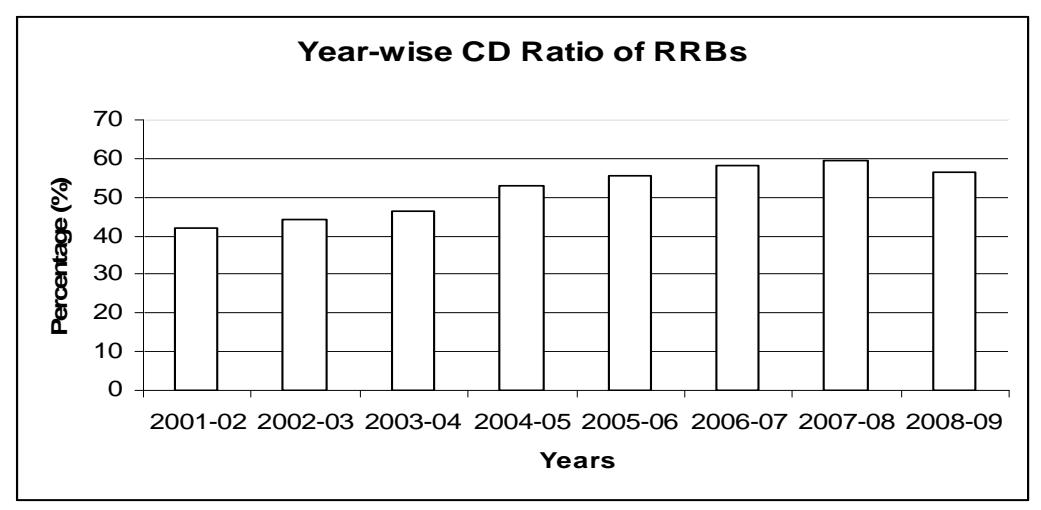

Table-11. Growth of Investments of RRBs in India (Rs.Crore)

\begin{tabular}{|l|l|l|}
\hline Years & Amount of Investment & \% of Increase over Previous Year \\
\hline $2001-02$ & 30,532 & --- \\
\hline $2002-03$ & 33,063 & 8.28 \\
\hline $2003-04$ & 36,135 & 9.29 \\
\hline $2004-05$ & 36,762 & 1.73 \\
\hline $2005-06$ & 41,182 & 12.02 \\
\hline $2006-07$ & 45,666 & 10.88 \\
\hline $2007-08$ & 48,560 & 6.33 \\
\hline $2008-09$ & 65,910 & 35.72 \\
\hline
\end{tabular}

Source: Central Statistical Information Department, NABARD, June-2009. 